\title{
Comparison of in vitro antioxidative activities of crude methanolic extracts of three species of Passiflora from greenhouse using DPPH, ABTS and FRAP methods
}

\author{
MARCIN OŻAROWSKI ${ }^{* *}$, AURELIA PIETROWIAK ${ }^{2}$, AGNIESZKA GRYSZCZYŃSKA ${ }^{2}$, \\ DOUGLAS SIGUEIRA DE A. CHAVES ${ }^{3}$, ANNA KRAJEWSKA-PATAN ${ }^{4}$, KAROLINA WIELGUS ${ }^{1}$, \\ AGNIESZKA SEREMAK-MROZIKIEWICZ2, 5,
}

${ }^{1}$ Department of Biotechnology

Institute of Natural Fibres and Medicinal Plants

Wojska Polskiego 71b

60-630 Poznań, Poland

${ }^{2}$ Department of Pharmacology and Phytochemistry

Institute of Natural Fibres and Medicinal Plants

Kolejowa 2

62-064 Plewiska, Poland

${ }^{3}$ Department of Pharmaceutical Science

Health and Biological Science Institute

Federal Rural University of Rio de Janeiro

Seropedica, RJ, Brazil

${ }^{4}$ Department of Botany, Breeding and Agricultural Technology of Medicinal Plants Institute of Natural Fibres and Medicinal Plants

Kolejowa 2

62-064 Plewiska, Poland

${ }^{5}$ Department of Perinatology and Women's Diseases

Poznań University of Medical Sciences

Polna 33

60-535 Poznań, Poland

${ }^{6}$ Laboratory of Molecular Biology

Poznań University of Medical Sciences

Polna 33

60-535 Poznań, Poland

*corresponding author: e-mail: marcin.ozarowski@iwnirz.pl 


\section{Summary}

Introduction:. It is well documented that many species from Passifloraceae family can provide edible and nutritious fruits while the leaves of cultivated plants are renewable and waste material. This biomass may be further used in various sectors, especially as a bioactive food additive and as source of innovative pharmaceuticals, cosmetics or feed additives. The biomaterials and green chemistry are new sectors bioeconomy according to the high-level horizontal strategies and bio-based industries in Europe. In recent years, attention has been paid to the biological activity and phytochemical profiles of extracts from different species of Passiflora. However, there is little comparative studies using the same procedures and techniques in the same laboratory conditions for study of plant material obtained from the similar greenhouse conditions.

Objective: This study was focused on the examination of antioxidative activities of low concentrations of crude extracts from leaves of Passiflora incarnata L., Passiflora caerulea L., and Passiflora alata Curtis.

Methods: The activity was evaluated using 2,2-diphenyl-1-picrylhydrazyl (DPPH), 2,2'-azino-bis (3-ethylbenzothiazoline-6-sulphonic acid) (ABTS) radical scavenging and ferric reducing antioxidant power (FRAP) methods. Results of study were supported by estimation of chemical composition with secondary metabolites profiling in extracts which were carried out previously for the same extracts from three Passiflora species. One-way ANOVA analysis revealed significant differences in the antioxidant activity of various concentrations of the extracts using the DPPH and ABTS radical models, and FRAP method.

Results: Measurement of antioxidant capacity (expressed as trolox equivalent, TE) showed that the most active was extract of $P$. caerulea $>P$. alata $>P$. incarnata. Phytochemical analysis for extracts of $P$. caerulea and $P$. incarnata showed greater similarities in metabolites content than $P$. alata. However, comparative statistical analysis of antioxidant activity showed that despite this phytochemical similarities, extract from $P$. alata leaves had higher activities than extract from leaves $P$. incarnata. Antioxidant effect of extract from $P$. alata can be explain by terpenoids presented in this extract. In this work, there have been discussed activities against Acanthamoeba castellanii strain, antibacterial and antifungal activities against selected clinical microorganisms (Enterococcus faecalis, Escherichia coli, Staphylococcus aureus, and Candida albicans, Microsporum gypseum), and anti-leukemic activities tested in human acute lymphoblastic leukemia cell lines for this extracts, which have been described in previous authors' publications.

Conclusion: Our current and previous studies showed that the same crude extracts from leaves of $P$. alata, $P$. caerulea, $P$. incarnata exerted not only antioxidant potential in vitro but also few interesting properties such as antibacterial, antifungal, amoebostatic, amoebicidal activities, which indicate the possibility of using these extracts in both a healthy diet and natural cosmetics. Leaves of this species may become an interesting source of biomaterials which can exert health-promoting effects.

Key words: passionflower, herbal extract, antioxidant activity, DPPH, ABTS, FRAP, phenolic compounds

Słowa kluczowe: passiflora, ekstrakt ziołowy, aktywność antyoksydacyjna, DPPH, ABTS, FRAP, związi fenolowe

\section{INTRODUCTION}

In many papers it has been showed that study on in vitro and in vivo models of oxidative stress is an important scientific area that serves human health and wellness. Some popular plant substances such as chemical compounds and extracts, i.e. from Camelia sinensis [1], Crataegus oxyacantha [2], Echinacea purpurea [3], Matricaria recutita [4], Rosa sp. [5], Oryza sativa [6], Rosmarinus officinalis [2, 7], Vitis vinifera [8] are still being investigated. Apart from this, further in vitro screenings of plant extracts containing various defined chemical compounds may essentially contribute to the discovery and development of new, clinically useful drugs of natural origin. Evaluation of the activity of plant extracts is a broad direction of search for new antioxidants with wide spectrum of pharmacological activity that can be used in the prevention of diseases involving oxidative stress in cells.

Nowadays, it is well known that oxidative stress is involved in pathophysiology of numerous progressive disorders, e.g. cardiovascular diseases, cancer development, neurodegenerative processes [9], diabetes 
[10], cognitive dysfunctions [11-13], amyotrophic lateral sclerosis [14], Huntington's disease [15], Parkinson's disease [15], Alzheimer's disease $[16,17]$ and other aging-associated diseases [18]. There is well documented that overproduction of reactive oxygen species (ROS) and reactive nitrogen species (RNS) can cause several harmful effects on molecular and cellular levels including degradation/depolimerization of macromolecules such as DNA, RNA, lipids, proteins, as well as polysaccharides leading to destabilization of membranes, causing damage and cell loss i.e. in the nervous system [15, 19-21]. Antioxidants such as phenolic compounds (flavonoids, tannins), lignins and dietary fiber are believed to be the principal nutrients which are responsible for these cytoprotective effects [21-23].

Plant extracts as a mixture of many chemical compounds may possess more interesting biological activities due to their components (among others aromatic plant pigments) can interact one with another and show antioxidant effect in depending on the extraction techniques i.e. using solvents with various polarity, microwave-assisted or ultrasonic-assisted extractions [22], non-thermal high hydrostatic pressure extraction [24] and supercritical extraction $[25,26]$. It is considered that obtaining plant extracts using fast and appropriate techniques is a low-cost method. Moreover, mixture of various chemical compounds in extracts may be active due to different antioxidative mechanisms $[22,23,27]$ as compared to single chemical compound. It should be also noted that combining antioxidants may increase their effectiveness. According to Brewer [23] many of the natural antioxidants (flavonoids and anthocyanins) have more than one aromatic ring and thus the effectiveness of these chemical compounds is generally proportional to the number of $-\mathrm{OH}$ groups present on the aromatic ring(s). The cytoprotective effects of flavonoids in various biological systems are depend on the complex mechanism of their activity such as capacity to transfer free radical electrons, chelate metal catalyst, activate antioxidant enzymes, reduce alpha-tocopherol radicals and inhibit oxidases [21].

There is strong scientific evidence that plant substances are a valuable source of natural antioxidants $[22,28-33]$ and can be applied in the production of nutraceuticals [1,30], pharmaceuticals [1], in healthy diet $[1,6,8,22,34]$, cosmetics [1], and nutricosmetics [35].

In recent years, attention has been paid to the biological activity of phytochemically defined extracts from different species of Passiflora which can be obtained not only from natural habitats of South America (mainly Colombia and Brazil), but also from controlled greenhouse cultivation in various countries or using biotechnological methods such as micropropagation in sterile and monitored in vitro laboratory conditions [36-43].

Passiflora alata, P. caerulea, P. incarnata are members of the Passifloraceae family. Aerial parts of Passiflora sp. provide raw material rich in phenolic and flavonoid compounds which possess wide range of antioxidant activities. Various species of Passiflora are among of the most trusted herbal medicines. In Europe, Passiflora incarnata L. is the most popular plant, included in the European Pharmacopoeia for the treatment of anxiety, insomnia, nervousness as sedatives $[36,44]$. However, beside of antioxidative study, there is a progress in discovery of molecular mechanism of action for chemical compounds occurring in extracts from Passiflora sp. especially apigenin derivatives (i.e. vitexin, isovitexin) and luteolin derivatives (i.e. orientin, isoorientin).

Antioxidative studies using in vitro and in vivo tests were carried out for various extracts from Passiflora species i.e. extract from fruits of $P$. foetida [45], ethanolic extract from pulp of $P$. alata [46], different solvent extracts from fruits of $P$. ligularis [47], dietary fiber powder from pulp and seeds or albedo of $P$. edulis var. flavicarpa [48], methanolic extract from pulp of $P$. glandulosa [49], methanolic extracts from peel of fruits, leaves and stems of $P$. palmeri var. sublanceolata, $P$. nitida, $P$. tenuifila, $P$. coriacea, P. foetida [50], extracts of peel of P. edulis [51, 52], of seeds of $P$. edulis [53], of bark (exocarpium and mesocarpium) of $P$. edulis [54], various preparations of $P$. incarnata [55-57], fruit juices from seven passion fruit (Passiflora spp.) cultivars: P. edulis cultivars Purple, Frederick, Yellow, Pink, P. edulis f. flavicarpa, P. maliformis and P. quadrangularis [58], aqueous extract from leaf of $P$. edulis [59,60], ethanolic and fractionated extract from leaf of $P$. mucronata [61], fractionated extracts from leaves and stems of $P$. quadrangularis and P. maliformis [62], of P. alata [63], hydroethanol leaf extract of $P$. nitida [64], acetone extract of P. subpeltata leaves [65]. However, it should be emphasized that results of these studies are different not only due to various solvents used in conventional extraction but also by different in vitro and in vivo methods used to estimate the antioxidant activity and by different species, part of plants, chemical composition and environmental factors influencing various horticultural crops of Passiflora in countries around the world. 
The aim of the current study was to investigate antioxidant activity using three common in vitro methods presented as DPPH, ABTS and FRAP of the crude methanolic extracts from leaves of most popular species such as Passiflora incarnata L., Passiflora caerulea L. and Passiflora alata Curtis cultivated in Poland. Results of studies were compared with those of phenolic compounds occurring in extracts, according to papers by Ożarowski et al. [37] and Hadaś et al. [43].

\section{MATERIAL AND METHODS}

\section{Plant material}

Mature and healthy leaves of $P$. incarnata, $P$. alata and $P$. caerulea were obtained from plants growing in the greenhouse of the Poznan University of Medical Sciences, Poland, in controlled conditions as follows: temperature range from $25^{\circ} \mathrm{C}$ to $40^{\circ} \mathrm{C}$, humidity $60-70 \%$, as described previously [37]. Plants were identified at the Department of Medicinal and Cosmetic Natural Products, Poznań University of Medical Sciences, and also by Jorge Ochoa from the Passiflora Society International and the Department of Horticulture, Long Beach City College (California, USA). The voucher specimens have been deposited in the Herbarium of the Institute of Natural Fibers and Medicinal Plants in Poznań, Poland [37]. Evaluation of biological activity of leaf extracts in range of their antioxidant assessment is a continuation of previous examinations of extracts that have been phytochemically characterized and described by Ożarowski et al. [37]. Thus, procedures such as conventional preparation of methanolic extracts from $5 \mathrm{~g}$ of leaves of $P$. alata, of $P$. caerulea, of $P$. incarnata; determination of total phenolic content with Folin-Ciocalteu reagent expressed as gallic acid; LC phytochemical profile comparison of extracts using HPLC-DAD-MS ${ }^{\mathrm{n}}$ and UPLC-MS/MS methods and results were described previously [37], however, results of these studies were also discussed along with antioxidant capacity of extracts.

\section{In vitro antioxidant assays}

Well-established in vitro tests with some modifications made for the estimation of antioxidant activity of extracts such as: DPPH, ABTS and FRAP were used in this study $[41,42]$.

\section{Scavenging ability measured by the DPPH radical assay}

The DPPH (2,2-diphenyl-1-picrylhydrazyl) radical scavenging activity of the extract was measured according to the modified method of Brand-Williams et al. [66]. Detailed procedure was described by Ożarowski et al. [41, 42]. In brief, after preparation of basal solution ( $1.0 \mathrm{~g}$ extracts in $50 \mathrm{ml}$ of ethanol), appropriate dilutions have been made (from $0.5 \mathrm{ml}$ to $2.5 \mathrm{ml}$ in $10 \mathrm{ml}$ of ethanol) and next $0.1 \mathrm{ml}$ of various dilutions was mixed with $3.9 \mathrm{ml}$ of $6 \times 10^{-5} \mathrm{~mol} / 1$ ethanol solution of the DPPH radical. Next, the decrease in the absorbance at $\lambda=515 \mathrm{~nm}$ was measured using a spectrophotometer (UV-VIS, Cintra 20, GBC Scientific Equipment Pty Ltd., Australia). The results were calculated as trolox equivalent antioxidant capacity (nM TE/100 g of extract).

\section{Scavenging ability measured by the ABTS radi- cal cation}

Free radical scavenging activity of extracts from leaves of $P$. alata, $P$. caerulea, $P$. incarnata, was determined according to the modified method of Re et al. [67] and detailed procedure was described previously by Ożarowski et al. [41]. In brief, after preparation of basal solution (as above), appropriate dilutions have been made (from $0.25 \mathrm{ml}$ to $1.75 \mathrm{ml}$ in $10 \mathrm{ml}$ of ethanol) and next $30 \mu \mathrm{l}$ of various dilutions was mixed with $3.0 \mathrm{ml}$ of the diluted ABTS+ solution. Next, absorbance was measured at $\lambda=734 \mathrm{~nm}$. The results were calculated as trolox equivalent antioxidant capacity ( $\mu \mathrm{M}$ TE/100 g of extract).

\section{Ferric reducing/antioxidant power assay (FRAP)}

The total antioxidant potential of extracts from leaves of $P$. alata, $P$. caerulea, $P$. incarnata was determined according to Benzie and Strain [68] with some modification, using the ferric-reducing ability of plasma FRAP assay. Detailed procedure was described previously by Ożarowski et al. [41, 42]. In brief, after preparation of basal solution (as above), appropriate dilutions have been made (from $0.125 \mathrm{ml}$ to $1.00 \mathrm{ml}$ in $10 \mathrm{ml}$ of ethanol) and next $0.1 \mathrm{ml}$ of various dilutions was mixed with $3.0 \mathrm{ml}$ of freshly prepared FRAP reagent and $0.3 \mathrm{ml}$ of water. This methods allowed to measure the changes in the absorbance at $593 \mathrm{~nm}$ after decolorization of blue-coloured product. The 
results were calculated as trolox equivalent antioxidant capacity ( $\mu \mathrm{M}$ TE/100 g of extract).

\section{Statistical analysis}

All measurements were performed in triplicate and all values were expressed as means \pm SEM. The statistical estimation was carried out using one-way analysis of variance (ANOVA) followed by Tuckey's post-hoc test for detailed data analysis using STATISTICA 11. The level of statistical significance was set at $p<0.05$. This statistical test has been applied because this kind of results meet the requirements of normal distribution of data.

Ethical approval: The conducted research is not related to either human or animal use.

\section{RESULTS AND DISCUSSION}

Phenolics and flavonoids have been reported to be the most important natural aromatic chemical compounds responsible for the antioxidant capacity of plant extracts [21, 47, 65]. Most studies evaluated biological and pharmacological activities of various species of Passiflora have been focused on antioxidant properties of extracts from fruits $[45,46,48$, $49,51,52,65]$. In our study, extracts from leaves of three species of Passiflora were investigated because the leaves may be a valuable source of biomass, which is not widely used for economic purposes, and during fruit collection from cultivated species, the leaves are being removed.

Our earlier phytochemical studies exerted total phenolic compound using Folin-Ciocalteu reagent (expressed as mg of gallic acid equivalent/g of extract) in the same methanolic extracts of $P$. alata $(8.21 \mathrm{mg} / \mathrm{g})$, P. caerulea $(6.23 \mathrm{mg} / \mathrm{g})$ and P. incarnata
(4.85 mg/g) [43]. Also, eighty two secondary metabolites have been previously identified in the same extracts using HPLC-DAD-MS ${ }^{\mathrm{n}}$ and UPLC-MS/MS. It was shown that the majority of these metabolites has been classified as phenolic compounds (flavonoids) [37]. O,C-glycosides of flavones apigenin, luteolin and chrysin were in the highest level in all Passiflora species ( $>60 \%$ in P. incarnata, $50 \%$ in P. caerulea, $40 \%$ in $P$. alata) but $C$-glycosides were observed in high content in P. caerulea and P. incarnata ( $>30 \%$ in PC, $>20 \%$ in P. incarnata). Moreover, phenolic acid derivatives constituted $18 \%, 11.5 \%$ and $5 \%$ of the area of identified peaks of $P$. alata, $P$. caerulea and $P$. incarnata, respectively. The highest content of terpenoids was identified in PA (38\% of the area of identified peaks). In all extracts also blumenol C glucoside was identified [37].

Antioxidant activity of the extracts has been measured by three different test systems (ABTS, DPPH and FRAP) according to the other authors [69]. ANOVA analysis revealed significant differences in the antioxidant activity of various concentrations of the extracts using the DPPH radical model in vitro for $P$. caerulea extract $(\mathrm{F}(4,10)=1629.831 ; p<0.001)$, for $P$. incarnata extract $(\mathrm{F}(4,10)=286.439, p<0.001)$ and for $P$. alata extract $(\mathrm{F}(4,10)=129.918, p<0.001)$. Detailed Tukey's post-hoc analysis showed that all concentrations used in the study exerted significant differences $(p<0.001)$. The DPPH radical scavenging capacity of the methanolic extracts was found to increase in a dose-dependent manner. The most active was $P$. caerulea extract (from $69.36 \pm 2.48$ to $276.51 \pm 1.15 \mathrm{nM}$ TE) in the investigated concentration range $>P$. alata extract (from $39.29 \pm 1.15$ to $149.45 \pm 7.09 \mathrm{nM} \mathrm{TE})>P$. incarnata extract (from $16.82 \pm 3.12$ to $77.71 \pm 0.37 \mathrm{nM} \mathrm{TE}$ ) (tab. 1 ).

ABTS radical scavenging test is one of the most extensively used antioxidant assays in plant extracts $[47,65]$. In this method, ANOVA analysis revealed significant differences in the antioxidant activity of

Table 1

$\mathrm{DPPH}$ radical scavenging capacities of the extracts expressed as trolox equivalent

\begin{tabular}{llccccc} 
& \multicolumn{5}{c}{ Inhibition of DPPH $[\mathrm{nM} \mathrm{TE}]$} \\
\cline { 2 - 6 } Extract & \multicolumn{5}{c}{ Concentration of extracts } & ANOVA \\
\cline { 2 - 7 } & $0.05[\mathrm{mg} / 0.1 \mathrm{ml}]$ & $0.1[\mathrm{mg} / 0.1 \mathrm{ml}]$ & $0.15[\mathrm{mg} / 0.1 \mathrm{ml}]$ & $0.2[\mathrm{mg} / 0.1 \mathrm{ml}]$ & $0.25[\mathrm{mg} / 0.1 \mathrm{ml}]$ & \\
\hline PA & $39.29 \pm 1.15^{*}$ & $77.89 \pm 0.68^{*}$ & $87.63 \pm 0.88^{*}$ & $121.88 \pm 3.98^{*}$ & $149.45 \pm 7.09^{*}$ & $\mathrm{~F}(4,10)=129.918, p<0.001$ \\
\hline PC & $69.36 \pm 2.48^{*}$ & $128.59 \pm 2.69^{*}$ & $159.62 \pm 1.58^{*}$ & $237.54 \pm 2.01^{*}$ & $276.51 \pm 1.15^{*}$ & $\mathrm{~F}(4,10)=1629.831, p<0.001$ \\
\hline PI & $16.82 \pm 3.12$ & $26.51 \pm 0.20$ & $49.60 \pm 0.57$ & $57.09 \pm 0.29$ & $77.71 \pm 0.37$ & $\mathrm{~F}(4,10)=286.439, p<0.001$ \\
\hline
\end{tabular}

Abbreviations: PA - Passiflora alata, PC - Passiflora caerulea, PI - Passiflora incarnata (PI)

Data are expressed as the means \pm SEM (three replicates)

${ }^{*}$ statistically significant difference vs. PI (control for PC and PA); $p<0.05$ 
various concentrations of the extracts from leaves of $P$. caerulea $(\mathrm{F}(4,10)=4018.782, p<0.001)$, of $P$. incarnata $(\mathrm{F}(4,10)=826.761, p<0.001)$, of $P$. alata $(\mathrm{F}(4,10)=60.069, p<0.001)$. Moreover, detailed Tukey's post-hoc analysis showed that all concentrations used in the study were significantly different $(p<0.001)$. The ABTS radical scavenging capacity of the extract was found to increase in a dose-dependent manner. Statistical analysis showed that most active was $P$. caerulea extract (from $4.15 \pm 0.01$ to $14.11 \pm 0.04 \mu \mathrm{M} \mathrm{TE}$ ) in the investigated concentration range $>P$. alata extract (from $2.06 \pm 0.01$ to $7.08 \pm 0.00 \mu \mathrm{M} \mathrm{TE})>P$. incarnata extract (from $1.82 \pm 0.01$ to $2.95 \pm 0.02 \mu \mathrm{M} \mathrm{TE}$ ) (tab. 2).

In the third method with use of the FRAP radical model, ANOVA analysis revealed significant differences in the antioxidant activity of various concentrations of the extracts from leaves of $P$. caerulea $(\mathrm{F}(4,10)=7749.99$, $p<0.001)$, of $P$. alata $(\mathrm{F}(4,10)=13306.33, p<0.001)$, of $P$. incarnata $(\mathrm{F}(4,10)=2278.21, p<0.001)$. Similarly, detailed Tukey's post-hoc analysis showed that all concentrations used in the study differed significantly $(p<0.001)$. The concentration of $\mathrm{Fe}(\mathrm{II})$ increased in a dose-dependent manner and it was observed that investigated concentration range $>P$. alata extract (from
$32.88 \pm 0.12$ to $301.04 \pm 1.49 \mu \mathrm{M} \mathrm{TE})>P$. incarnata extract (from $34.21 \pm 0.21$ to $133.77 \pm 0.38 \mu \mathrm{M} \mathrm{TE}$ ) (tab. 3).

Significant positive correlations (Pearson's correlation coefficient) were found between the results for $P$. caerulea, $P$. incarnata and $P$. alata extracts using DPPH test $(\mathrm{r}=0.9923, \mathrm{r}=0.9850, \mathrm{r}=0.9799$, respectively, $p<0.05)$, using ABTS test $(\mathrm{r}=0.9894$, $\mathrm{r}=0.9925, \mathrm{r}=0.9781$, respectively, $p<0.05)$ and using FRAP method $(\mathrm{r}=0.9933, \mathrm{r}=0.9248, \mathrm{r}=0.9939$, respectively, $p<0.05)$.

Earlier studies showed that various extracts from leaves of many Passiflora species contain these groups of phytochemicals and they may have contributed to their excellent radical scavenging ability. Most studies were carried out for extracts from fruits of P. edulis [48, 51-60]. To the best of our knowledge, any studies evaluating the antioxidant activity of the methanol extract of $P$. caerulea leaves have been conducted so far.

De Araujo et al. [61] evaluated the crude hydroalcoholic extract and fractions from leaves of $P . m u$ cronata from Rio de Janeiro (Brazil) using in vitro antioxidant activity assay of DPPH radical. Results of this study showed value $\mathrm{EC}_{50}=96.05 \mu \mathrm{g} / \mathrm{ml}$ for

Table 2

ABTS radical scavenging capacities of the extracts expressed as trolox equivalent

\begin{tabular}{llllrll} 
& \multicolumn{5}{c}{ Inhibition of ABTS $[\mu \mathrm{M} \mathrm{TE}]$} & \multirow{2}{*}{ ANOVA } \\
\cline { 2 - 6 } Extract & \multicolumn{5}{c}{ Concentration of extracts } \\
\cline { 2 - 6 } & 0.0075 & 0.03 & 0.038 & 0.045 & 0.052 \\
& {$[\mathrm{mg} / 0.03 \mathrm{ml}]$} & {$[\mathrm{mg} / 0.03 \mathrm{ml}]$} & {$[\mathrm{mg} / 0.03 \mathrm{ml}]$} & {$[\mathrm{mg} / 0.03 \mathrm{ml}]$} & $7.03 \mathrm{ml}]$ & \\
\hline PA & $2.06 \pm 0.01^{*}$ & $4.46 \pm 0.10^{*}$ & $5.15 \pm 0.39^{*}$ & $6.25 \pm 0.38^{*}$ & $7.08 \pm 0.00^{*}$ & $\mathrm{~F}(4,10)=60.069, p<0.001$ \\
\hline PC & $4.15 \pm 0.01^{*}$ & $8.65 \pm 0.07^{*}$ & $9.46 \pm 0.07^{*}$ & $11.78 \pm 0.07^{*}$ & $14.11 \pm 0.04^{*}$ & $\mathrm{~F}(4,10)=4018.782, p<0.001$ \\
\hline PI & $1.82 \pm 0.01$ & $2.37 \pm 0.02$ & $2.58 \pm 0.01$ & $2.88 \pm 0.05$ & $2.95 \pm 0.02$ & $\mathrm{~F}(4,10)=826.761, p<0.001$ \\
\hline
\end{tabular}

Abbreviations: PA - Passiflora alata, PC - Passiflora caerulea, PI - Passiflora incarnata (PI)

Data are expressed as the mean \pm SEM (three replicates)

*statistically significant difference $v s$. PI (control for PC and PA); $p<0.05$

Table 3

FRAP $[\mu \mathrm{M} \mathrm{Fe} 2+/ 1]$ after the extracts expressed as trolox equivalent

\begin{tabular}{|c|c|c|c|c|c|c|}
\hline \multirow{3}{*}{ Extract } & \multicolumn{5}{|c|}{ FRAP $[\mu \mathrm{M}$ Fe $2+/ l$ expressed as $\mu \mathrm{M}$ TE $]$} & \multirow{3}{*}{ ANOVA } \\
\hline & \multicolumn{5}{|c|}{ Concentration of extracts } & \\
\hline & $\begin{array}{l}0.0125 \\
{[\mathrm{mg} / 0.1 \mathrm{ml}]}\end{array}$ & $\begin{array}{l}0.025 \\
{[\mathrm{mg} / 0.1 \mathrm{ml}]}\end{array}$ & $0.050[\mathrm{mg} / 0.1 \mathrm{ml}]$ & $0.075[\mathrm{mg} / 0.1 \mathrm{ml}]$ & $0.10[\mathrm{mg} / 0.1 \mathrm{ml}]$ & \\
\hline $\mathrm{PA}$ & $32.88 \pm 0.12$ & $64.80 \pm 0.09^{*}$ & $149.16 \pm 0.38^{*}$ & $196.77 \pm 1.38^{*}$ & $301.04 \pm 1.49^{*}$ & $\mathrm{~F}(4,10)=13306.33, p<0.001$ \\
\hline PC & $59.82 \pm 0.68^{\star}$ & $128.32 \pm 1.37^{*}$ & $265.48 \pm 2.32^{\star}$ & $362.98 \pm 1.96^{*}$ & $443.37 \pm 2.18^{\star}$ & $\mathrm{F}(4,10)=7749.99, p<0.001$ \\
\hline PI & $34.21 \pm 0.21$ & $43.58 \pm 0.32$ & $83.92 \pm 1.61$ & $100.62 \pm 0.89$ & $133.77 \pm 0.38$ & $\mathrm{~F}(4,10)=2278.21, p<0.001$ \\
\hline
\end{tabular}

Abbreviations: PA - Passiflora alata, PC - Passiflora caerulea, PI - Passiflora incarnata (PI)

Data are expressed as the means \pm SEM (three replicates)

*statistically significant difference $v s$. PI (control for PC and PA); $p<0.05$ 
crude extract, and value $\mathrm{EC}_{50}=14.61 \mu \mathrm{g} / \mathrm{ml}$ for ethyl acetate fraction. Other authors [65] showed that the methanolic extract of $P$. subpeltata leaves exerted activity in FRAP test (1841.11 $\mathrm{mmol} \mathrm{Fe}{ }^{2+} / \mathrm{mg}$ extract), ABTS $(3357.60 \mu \mathrm{M}$ trolox equivalent/g extract) and $\mathrm{DPPH}\left(\mathrm{IC}_{50}=66.96 \mu \mathrm{g} / \mathrm{ml}\right)$ cation radical scavenging activities. In this study observed higher FRAP, ABTS and DPPH cation radical scavenging activities of extracts cold be attributed to the high level of polyphenolic content in extract from $100 \mathrm{~g}$ of leaves of $P$. subpeltata. In the next study, Colomeu et al. [63], using the same methods (FRAP, ABTS, DPPH) and ORAC (oxygen radical absorbance capacity), observed that the aqueous extract from leaves) of $P$. alata exerted the highest antioxidant activity as compared to ethanolic and methanolic extracts $(226.9 \mu \mathrm{M} \mathrm{FeSO} / \mathrm{g} ; 14.1 \mu \mathrm{M} \mathrm{FeSO} / \mathrm{g} ; 199.5 \mu \mathrm{M}$ $\mathrm{FeSO}_{3} / \mathrm{g}$ ) in model of mice with diabetes mellitus. Moreover, this extract was able to reduce the DPPH (56\% after aqueous extract, $38.4 \%$ after ethanol extract, $41.3 \%$ after methanol extract) and ABTS (3439 $\mu \mathrm{M}$ trolox/g after aqueous extract, $1733 \mu \mathrm{M}$ trolox/g after ethanol extract, $1127 \mu \mathrm{M}$ trolox/g methanol extract) and these results correlated with total phenols (9.5 mg EAG/g, $5.5 \mathrm{mg}$ EAG/g, $4.9 \mathrm{mg}$ EAG/g). In next study, Ramaiya et al. [62] showed that the methanolic extract of $P$. maliformis leaves had the strongest antioxidant activity in comparison to the extracts of $P$. quadrangularis and $P$. edulis using DPPH radicals $\left(\mathrm{EC}_{50}=456.9 \mu \mathrm{g} / \mathrm{ml}\right)$. Masteikova et al. [57], noted that the ethanol extract of aerial part of $P$. incarnata conjugated free radicals more effectively than the water extract (DPPH by over $70 \%$, ABTS by $60 \%$ ). These antioxidant properties were linked with flavonoids determined in the ethanol extract (mainly vicenin, vitexin, isovitexin, orientin). In comparison, recently Panelli et al. [54] exerted that extract from the fruit bark (exocarpium and mesocarpium) of $P$. edulis increased the antioxidant capacity in vivo in plasma, kidney, liver, adipose tissue of $\mathrm{db} / \mathrm{db}$ mice by inhibition of 4,4-difluoro-5-(4-phenyl-1,3-butadienyl)-4-bora3a,4a-diaza-s-indacene-3-undecanoic acid and also reduced the lipid oxidation in kidney and liver using method with malondialdehyde. In vitro test showed additionally that this extract inhibited DPPH with value $1.1 \mu \mathrm{M}$ equiv. trolox/100 g DW. Moreover, Kandandapani et al. [51] observed that ethanol extracts fruits of $P$. edulis significantly increased of superoxide dismutase (SOD) and catalase (CAT) and decrease in thiobarbituric acid reactive species (TBARS) level in heart, liver and kidneys of diabetic rats treated with extract at dose $500 \mathrm{mg} / \mathrm{kg}$.
Comparative antioxidant study using three in vitro models allowed us to conclude that all extracts demonstrated moderate antiradical activities, but the most active one was $P$. caerulea extract in comparison with $P$. alata and $P$. incarnata. The antioxidant activity of methanolic extracts of $P$. alata, $P$. caerulea, $P$. incarnata observed in these studies can expand of previously demonstrated in our studies four in vitro pharmacological properties of the same methanolic extracts, such as: amoebostatic and amoebicidal activities against Acanthamoeba castellanii strain (PA $>$ PC $>$ PI extracts) [43], antibacterial and antifungal activities against selected clinical microorganisms (Enterococcus faecalis, Escherichia coli, Staphylococcus aureus, and Candida albicans, Microsporum gypseum) [40], and anti-leukemic activities, tested in human acute lymphoblastic leukemia cell lines (CCRF-CEM) (PA>PI extracts) [37]. It is well known, that reactive oxygen species triggers oxidative stress in various cell types and contributes to the development, progression, and persistence of cancer [70]. The recent findings support important role for reactive oxygen species in the pathogenesis of leukemia and outline innovative approaches in the implementation of redox therapies for myeloid malignancies [70]. Results of our study can be taken into account in this field.

In conclusion, our studies showed that crude extracts from leaves of $P$. alata, $P$. caerulea, $P$. incarnata exerted few interesting in vitro pharmacological properties such as antibacterial, antifungal, amoebostatic, amoebicidal activities, and antioxidant potential, which indicates the possibility of using these extracts both in a healthy diet and natural cosmetics. On the other hand, antioxidant and anti-leukemic potential of extracts from leaves of $P$. alata, with the highest content of phenolic compounds, indicates new source of herbal drug for complementary therapy for cancer patients.

\section{ACKNOWLEDGMENTS}

Authors thank to prof. Gerard Nowak from Department of Medicinal and Cosmetic Natural Products, Poznań University of Medical Sciences for supervision of passiflora growing in a greenhouse, and to prof. Jaromir Budzianowski from Department of Pharmaceutical Botany and Plant Biotechnology, Poznań University of Medical Sciences for supervising the TLC identification for extracts of passiflora.

Conflict of interest: Authors declare no conflict of interest. 


\section{REFERENCES}

1. Tang GY, Zhao CN, Xu XY, Gan RY, Cao SY, Liu $\mathrm{Q}$, et al. Phytochemical composition and antioxidant capacity of 30 Chinese teas. Antioxidants (Basel). 2019; 8(6). pii: E180. doi: http://dx.doi. org/10.3390/antiox 8060180

2. Martínez-Rodríguez JL, Gutiérrez-Hernández R, Reyes-Estrada CA, Granados-López AJ, PérezVeyna O, Arcos-Ortega T, et al. Hepatoprotective, antihyperlipidemic and radical scavenging activity of hawthorn (Crataegus oxyacantha) and rosemary (Rosmarinus officinalis) on alcoholic liver disease. Altern Ther Health Med 2019; 25(4):54-63.

3. Karg CA, Wang P, Vollmar AM, Moser S. Reopening the stage for Echinacea research - characterization of phylloxanthobilins as a novel antioxidative compound class in Echinacea purpurea. Phytomedicine 2019:152969. doi: http://dx.doi. org/10.1016/j.phymed.2019.152969

4. Al-Dabbagh B, Elhaty IA, Elhaw M, Murali C, Al Mansoori A, Awad B, et al. Antioxidant and anticancer activities of chamomile (Matricaria recutita L.). BMC Res Notes 2019; 12(1):3. doi: http:// dx.doi.org/10.1186/s13104-018-3960-y

5. Fascella G, D’Angiolillo F, Mammano MM, Amenta M, Romeo FV, Rapisarda, et al. Bioactive compounds and antioxidant activity of four rose hip species from spontaneous Sicilian flora. Food Chem 2019; 289:56-64. doi: http://dx.doi. org/10.1016/j.foodchem.2019.02.127

6. Dittgen CL, Hoffmann JF, Chaves FC, Rombaldi CV, Filho JMC, Vanier NL. Discrimination of genotype and geographical origin of black rice grown in Brazil by LC-MS analysis of phenolics. Food Chem 2019; 288:297-305. doi: http://dx.doi. org/10.1016/j.foodchem.2019.03.006

7. Bañares C, Martin D, Reglero G, Torres CF. Protective effect of hydroxytyrosol and rosemary extract in a comparative study of the oxidative stability of Echium oil. Food Chem 2019; 290:316-323. doi: http://dx.doi.org/10.1016/j. foodchem.2019.03.141

8. Loizzo MR, Sicari V, Pellicanò T, Xiao J, Poiana $\mathrm{M}$, Tundis R. Comparative analysis of chemical composition, antioxidant and anti-proliferative activities of Italian Vitis vinifera by-products for a sustainable agro-industry. Food Chem Toxicol 2019; 127:127-134. doi: http://dx.doi. org/10.1016/j.fct.2019.03.007

9. Cenini G, Lloret A, Cascella R. Oxidative stress in neurodegenerative diseases: from a mitochondrial point of view. Oxid Med Cell Longev 2019; 2019:2105607. doi: http://dx.doi. org/10.1155/2019/2105607

10. Newsholme P, Keane KN, Carlessi R, Cruzat V. Oxidative stress pathways in pancreatic beta cells and insulin sensitive cells and tissues - importance to cell metabolism, function and dysfunction. Am J Physiol Cell Physiol 2019. doi: http:// dx.doi.org/10.1152/ajpcell.00141.2019

11. Lejri I, Agapouda A, Grimm A, Eckert A. Mitochondria- and oxidative stress-targeting substances in cognitive decline-related disorders: from molecular mechanisms to clinical evidence. Oxid Med Cell Longev 2019; 2019:1-26. doi: http://dx.doi.org/10.1155/2019/9695412

12. Hajjar I, Hayek SS, Goldstein FC, Martin G, Jones DP, Quyyumi A. Oxidative stress predicts cognitive decline with aging in healthy adults: an observational study. J Neuroinflammation 2018; 15:17. doi: http://dx.doi.org/doi.org/10.1186/ s12974-017-1026-Z

13. Pesce M, Tatangelo R, La Fratta I, Rizzuto A, Campagna G, Turli C, et al. Aging-related oxidative stress: positive effect of memory training. Neurosci 2018; 370:246-255. doi: http://dx.doi. org/10.1016/j.neuroscience.2017.09.046

14. Chi L, Ke Y, Luo C, Gozal D, Liu R. Depletion of reduced glutathione enhances motor neuron degeneration in vitro and in vivo. Neurosci 2007; 144:991-1003. doi: http://dx.doi.org/10.1016/j. neuroscience.2006.09.064

15. Manoharan S, Guillemin GJ, Abiramasundari RS, Essa MM, Akbar M, Akbar MD. The role of reactive oxygen species in the pathogenesis of Alzheimer's disease, Parkinson's disease, and Huntington's disease: a mini review. Oxid Med Cell Longev 2016; 2016: ID 8590578. doi: http:/ dx./doi.org/10.1155/2016/8590578

16. Cheignon C, Tomas M, Bonnefont-Rousselot D, Faller P, Hureau C, Collin F. Oxidative stress and the amyloid beta peptide in Alzheimer's disease. 
Redox Biol 2018; 14:450-464. doi: http://dx.doi. org/10.1016/j.redox.2017.10.014

17. Hatanaka H, Hanyu H, Hirose D, Fukusawa R, Namioka N, Iwamoto T. Peripheral oxidative stress markers in individuals with Alzheimer's disease with or without cerebrovascular disease. J Am Geriatr Soc 2015; 63(7):1472-1474. doi: http://dx.doi.org/10.1111/jgs.13549

18. Conti V, Izzo V, Corbi G, Russomanno G, Manzo V, De Lise F, Di Donato A, Filippelli A. Antioxidant supplementation in the treatment of aging-associated diseases. Front Pharmacol 2016; 7(24):1-11. doi: http://dx.doi.org/10.3389/ fphar.2016.00024

19. Diaz-Hung ML, Gonzalez FME. Oxidative stress in neurological diseases: Cause or effect? Neurología 2014; 29(8):451-452. doi: http://dx.doi. org/10.1016/j.nrl.2013.06.022

20. Duan J, Kasper DL. Oxidative depolymerization of polysaccharides by reactive oxygen/nitrogen species. Glycobiol 2011; 21(4): 401-409. doi: http://dx.doi.org/10.1093/glycob/cwq171

21. Grotewold E. The science of flavonoids. Springer Science + Business Media, LLC, New York, 2008, p. 215.

22. Altemimi A, Lakhssassi N, Baharlouei A, Watson DG, Lightfoot DA. Phytochemicals: extraction, isolation, and identification of bioactive compounds from plant extracts. Plants (Basel) 2017; 6(42):1-23. doi: http://dx.doi.org/10.3390/ plants6040042

23. Brewer MS. Natural antioxidants: sources, compounds, mechanisms of action, and potential applications. Compr Rev Food Ssci 2011; 10(4):221-247. doi: http:/dx./doi.org/10.1111/j.1541-4337.2011.00156.x

24. Scepankova H, Martins M, Estevinho L, Delgadillo I, Saraiva JA. Enhancement of bioactivity of natural extracts by non-thermal high hydrostatic pressure extraction. Plant Foods Hum Nutr 2018; 73(4):253-267. doi: http://dx.doi.org/10.1007/ s11130-018-0687-9

25. Devequi-Nunes D, Machado BAS, Barreto GA, Rebouças Silva J, da Silva DF, da Rocha JLC, et al. Chemical characterization and biological activity of six different extracts of propolis through con- ventional methods and supercritical extraction. PLoS One 2018; 13(12):e0207676. doi: http:// dx.doi.org/10.1371/journal.pone.0207676

26. Machado BA, Gde AB, Costa AS, Costa SS, Silva $\mathrm{RP}$, da Silva DF, et al. Determination of parameters for the supercritical extraction of antioxidant compounds from green propolis using carbon dioxide and ethanol as co-solvent. PLoS One 2015; 10(8):e0134489. doi: http://dx.doi.org/10.1371/ journal.pone.0134489

27. Cherrak SA, Mokhtari-Soulimane N, Berroukeche F, Bensenane B, Cherbonnel A, Merzouk $\mathrm{H}$, et al. In vitro antioxidant versus metal ion chelating properties of flavonoids: a structureactivity investigation. PLoS One 201611(10): e0165575. doi: http://dx.doi.org/10.1371/journal. pone. 0165575

28. Ginwala R, Bhavsar R, Chigbu DeGI, Jain P, Khan ZK. Potential role of flavonoids in treating chronic inflammatory diseases with a special focus on the anti-inflammatory activity of apigenin. Antioxidants 2019; 8:35. doi: http://dx.doi.org/10.3390/ antiox8020035

29. Zimniewska M, Różańska W, Gryszczyńska A, Romanowska B, Kicinska-Jakubowska A. Antioxidant potential of hemp and flax fibers depending on their chemical composition. Molecules 2018; 23:1993. doi: http://dx.doi.org/10.3390/ molecules23081993

30. Brasanac-Vukanovic S, Mutic J, Stankovic DM, Arsic I, Blagojevic N, Vukasinovic-Pesic V, et al. Wild Bilberry (Vaccinium myrtillus L., Ericaceae) from Montenegro as a source of antioxidants for use in the production of nutraceuticals. Molecules 2018; 23:1864. doi: http:/dx./doi.org/10.3390/ molecules23081864

31. Grzegorczyk-Karolak I, Kiss AK. Determination of the phenolic profile and antioxidant properties of Salvia viridis L. shoots: a comparison of aqueous and hydroethanolic extracts. Molecules 2018; 23:1468. doi: http://dx.doi.org/10.3390/ molecules23061468

32. Bendif H, Boudjeniba M, Miara MD, Biqiku L, Bramucci M, Caprioli G, et al. Rosmarinus eriocalyx: an alternative to Rosmarinus officinalis as a source of antioxidant compounds. Food Chem 2017; 218:78-88. doi: http://dx.doi.org/10.1016/j. 
foodchem.2016.09.063

33. Jeong SC, Tulasi R, Koyyalamudi SR. Antioxidant capacities of hot water extracts and endopolysaccharides of selected Chinese medicinal fruits. Cancers 2016; 8:33. doi: http:/dx.doi.org/10.3390/ cancers 8030033

34. Rodriguez ES, Julio LM, Henning C, Diehl BW, Tomás MC, Ixtaina VY. Effect of natural antioxidants] on the physicochemical properties and stability of freeze-dried microencapsulated chia seed oil. J Sci Food Agric 2019; 99(4):1682-1690. doi: http://dx.doi.org/10.1002/jsfa.9355

35. Kania-Dobrowolska M, Baraniak J, Kujawski R, Ożarowski M. Nutricosmetic - new subgroup of dietary supplements. Post Fitoter 2017; 18(2):132-113. doi: http:/dx./doi.org/10.25121/ PF.2017.16.2.132

36. Ożarowski M, Thiem B. Progress in micropropagation of Passiflora spp. to produce medicinal plants. A mini-review. Rev Bras Farmacogn 2013: 23(6):937-947. doi: http://dx.doi.org/10.1590/ S0102-695X2013000600011

37. Ożarowski M, Piasecka A, Paszel-Jaworska A, Chaves DS, Romaniuk A, Rybczyńska M, et al. Comparison of bioactive compounds content in leaf extracts of Passiflora incarnata, P. caerulea and $P$. alata and in vitro cytotoxic potential on leukemia cell lines. Rev Bras Farmacogn 2018; 28:79-191. doi: http://dx.doi.org/10.1016/j. bjp.2018.01.006

38. Ożarowski M. Influence of the physico-chemical factors, plant growth regulators, elicitors and type of explants on callus culture of medicinal climbers of Passiflora L. Herba Pol 2011; 57(4):58-75.

39. Ożarowski M, Mikołajczak PŁ Thiem B. Medicinal plants in the phytotherapy of alcohol or nicotine addiction. Implication for plants in vitro cultures. Medical Rev (Przegl Lek) 2013; 70(10): 869-874.

40. Ożarowski M, Kędzia B, Kania-Dobrowolska M, Baraniak J, Gryszczyńska A, Opala B, et al. Porównanie aktywności wyciągów z liści Passiflora alata, $P$. caerulea i $P$. incarnata wobec wybranych drobnoustrojów klinicznych. Post Fitot 2018; 2:3-8. [in Polish]. doi: http://dx.doi.org/10.25121/ PF.2018.19.2.75
41. Ożarowski M, Kujawski R, Mikołajczak P, Gryszczyńska A, Pietrowiak A, Białas W, et al. Comparison of antioxidant activities of fractionated extracts from seedlings and herb of Chelidonium majus L. using DPPH, ABTS and FRAP methods. Herba Pol 2016; 4:22-38. doi: http:// dx.doi.org/10.1515/hepo-2016-0020

42. Ożarowski M, Piasecka A, Gryszczyńska A, Sawikowska A, Pietrowiak A, Opala B, et al. Determination of phenolic compounds and diterpenes in roots of Salvia miltiorrhiza and Salvia przewalskii by two LC-MS tools: multi-stage and high resolution tandem mass spectrometry with assessment of antioxidant capacity. Phytochem Lett 2017; 20:331-338. doi: http://dx.doi.org/ 10.1016/j.phytol.2016.12.001

43. Hadaś E, Ożarowski M, Derda M, Thiem B, Cholewiński M, Skrzypczak Ł, Gryszczyńska A, Piasecka A. The use of extracts from Passiflora spp. in helping the treatment of acanthamoebiasis. Acta Pol Pharm 2017; 74:921-928.

44. Ożarowski A. (red.). Ziołolecznictwo. Poradnik dla lekarzy. Wydawnictwo Lekarskie PZWL, Warszawa 1982, 198-199.

45. Song Y, Wei XQ, Li MY, Duan XW, Sun YM, Yang $R L$ et al. Nutritional composition and antioxidant properties of the fruits of a Chinese wild Passiflora foetida. Molecules 2018; 23: 459. doi: http:/ dx./doi.org/10.3390/molecules23020459

46. Zeraik ML, Serteyn D, Deby-Dupont G, Wauters $\mathrm{JN}$, Tits M, Yariwake JH, et al. Evaluation of the antioxidant activity of passion fruit (Passiflora edulis and Passiflora alata) extracts on stimulated neutrophils and myeloperoxidase activity assays. Food Chem 2011; 128(2): 259-265. doi: http://dx.doi. org/doi.org/10.1016/j.foodchem.2011.03.001

47. Saravanan S, Parimelazhagan T. In vitro antioxidant, antimicrobial and anti-diabetic properties of polyphenols of Passiflora ligularis Juss. fruit pulp. Food Sci Hum Wellness 2014; 3:56-64. doi: http://dx.doi.org/10.1016/j.fshw.2014.05.001

48. Lopez-Vargas JH, Fernández-López J, Pérez-Álvarez JA, Viuda-Martos M. Chemical, physicochemical, technological, antibacterial and antioxidant properties of dietary fiber powder obtained from yellow passion fruit (Passiflora edulis var. flavicarpa) co-products. Food Res Int 2013; 
51:756-763. doi: http://dx.doi.org/10.1016/j. foodres.2013.01.055

49. Lima-Neto ABM, Marques MM, Mendes FN, Vieira IG, Diniz DB, Guedes MI. Antioxidant activity and physicochemical analysis of passion fruit (Passiflora glandulosa Cav.) pulp native to Cariri region. Acta Sci Biol Sci 2017; 39(4):417422. doi: http://dx.doi.org/10.4025/actascibiolsci. v39i4.34045

50. Bendini A, Cerretani L, Pizzolante L, Toschi TG, Guzzo F, Ceoldo S, et al. Phenol content related to antioxidant and antimicrobial activities of Passiflora spp. extracts. Eur Food Res Technol 2006; 223:102-109. doi: http://dx.doi.org/10.1007/ s00217-005-0150-7

51. Kandandapani S, Balaraman AK, Ahamed HN. Extracts of passion fruit peel and seed of Passiflora edulis (Passifloraceae) attenuate oxidative stress in diabetic rats. Chin J Nat Med 2015; 13(9):0680-0686. doi: http://dx.doi.org/10.3724/ SP.J.1009.2015.00680

52. Wong YS, Sia CM, Khoo HE, Ang YK, Chang SK, Chang SK, Yim HS. Influence of extraction conditions on antioxidant properties of passion fruit (Passiflora edulis) peel. Acta Sci Pol Technol Aliment 2014; 13(3):257-65.

53. Lourith N, Kanlayvattanakul M. Antioxidant activities and phenolics of Passiflora edulis seed recovered from juice production residue. J Oleo Sci 2013; 62(4):235-240.

54. Panelli MF, Pierine DT, de Souza SLB, Ferron AJT, Garcia JL, dos Santos KC. Bark of Passiflora edulis treatment stimulates antioxidant capacity, and reduces dyslipidemia and body fat in $\mathrm{db} / \mathrm{db}$ mice. Antioxidants 2018; 7:120. doi: http://dx.doi.org/ 10.3390/antiox7090120

55. Boll KM, Bortolasci CC, Zaminelli T, Veríssimo LF, Bacchi AD, Higachi L et al. Passiflora incarnata treatment during gestation and lactation: toxicological and antioxidant evaluation in $\mathrm{Wi}$ star dams. Braz J Pharm Sci 2014; 50(2):353359. doi: http:/dx./doi.org/10.1590/S198482502014000200015

56. Ingale SP, Kasture SB. Antioxidant and antiparkinsonian activity of Passiflora incarnata leaves. Orient Pharm Exp Med 2014; 14:231-236. doi: http://dx.doi.org/10.1007/s13596-014-0149-3

57. Masteikova R, Bernatoniene J, Bernatoniene R, Velziene S. Antiradical activities of the extract of Passiflora incarnata. Acta Pol Pharm 2008; 65:577-583.

58. Ramaiya SD, Bujang JS, Zakaria MH, Kinga WS, Sahrir MAS. Sugars, ascorbic acid, total phenolic content and total antioxidant activity in passion fruit (Passiflora) cultivars. J Sci Food Agric 2013; 93:11981205. doi: http://dx.doi.org/10.1002/jsfa.5876

59. Cazarin CBB, da Silva JK, Colomeu TC, Batista AG, Meletti LMM, Paschoal JAR et al. Intake of Passiflora edulis leaf extract improves antioxidant and anti-inflammatory status in rats with 2,4,6-trinitrobenzenesulphonic acid induced colitis. J Funct Foods 2015; 17:575-586. doi: http:/ dx./doi.org/10.1016/j.jff.2015.05.034

60. da Silva JK, Cazarina CBB, Colomeu TC, Batista AG, Melettic LMM, Paschoal JAR et al. Antioxidant activity of aqueous extract of passion fruit (Passiflora edulis) leaves: In vitro and in vivo study. Food Res Int 2013; 53:882-890. doi: http:// dx.doi.org/10.1016/j.foodres.2012.12.043

61. de Araujo MH, da Silvac ICV, de Oliveira PF, Barreto ARR, Konno TUP, Esteves FA. et al. Biological activities and phytochemical profile of Passiflora mucronata from the Brazilian resting. Rev Bras Farmacogn 2017; 27:702-710. doi: http:// dx.doi.org/10.1016/j.bjp.2017.07.005

62. Ramaiya SD, Bujang JS, Zakaria MH. Assessment of total phenolic, antioxidant, and antibacterial activities of Passiflora species. Sci World J 2014; 2014: ID 167309, 10 pages. doi: http://dx.doi. org/10.1155/2014/167309

63. Colomeu TC, Figueiredo D, Cazarin CB, Schumacher NS, Marostica MR Jr., Meletti LM, et al. Antioxidant and anti-diabetic potential of Passiflora alata Curtis aqueous leaves extract in type 1 diabetes mellitus (NOD-mice). Int Immunopharmacol 2014; 18:106-115. doi: http://dx.doi. org/10.1016/j.intimp.2013.11.005

64. Montefusco-Pereira CV, de Carvalho MJ, de Araújo Boleti AP, Teixeira LS, Matos HR, Lima ES. Antioxidant, anti-inflammatory, and hypoglycemic effects of the leaf extract from Passiflora nitida Kunth. Appl Biochem Biotechnol 2013; 
170:1367-1378. doi: http://dx.doi.org/10.1007/ s12010-013-0271-6

65. Saravanan S, Karuppusamy A, Parimelazhagan T. Antioxidant, analgesic, anti-inflammatory and antipyretic effects of polyphenols from Passiflora subpeltata leaves - a promising species of Passiflora. Ind Crop Prod 2014; 54:272-280. doi: http:// dx.doi.org/10.1016/j.indcrop.2014.01.038

66. Brand-Williams W, Cuvelier ME, Berset C. Use of free radical method to evaluate antioxidant activity. Lebenson Wiss Technol 1995; 28:25-30.

67. Re R, Pellegrini N, Proteggente A, Pannala A, Yang M, Rice-Evans C. Antioxidant activity applying an improved ABTS radical cation decolorization assay. Free Radical Biol Med 1999; 26:1231-1237.
68. Benzie IF, Strain JJ. The ferric reducing ability of plasma (FRAP) as measurement of 'antioxidant power': The FRAP assay. Anal Biochem 1996; 239:70-76.

69. Martínez R, Torres P, Meneses MA, Figueroa JG, Pérez-Álvarez JA, Viuda-Martos M. Chemical, technological and in vitro antioxidant properties of mango, guava, pineapple and passion fruit dietary fibre concentrate. Food Chem 2012; 135(3):1520-1526. doi: http://dx.doi. org/10.1016/j.foodchem.2012.05.057

70. Zhou F, Qiang S, Claret FX. Novel roles of reactive oxygen species in the pathogenesis of acute myeloid leukemia. J Leukoc Biol 2013; 94(3):423429. doi: http://dx.doi.org/10.1189/jlb.0113006 